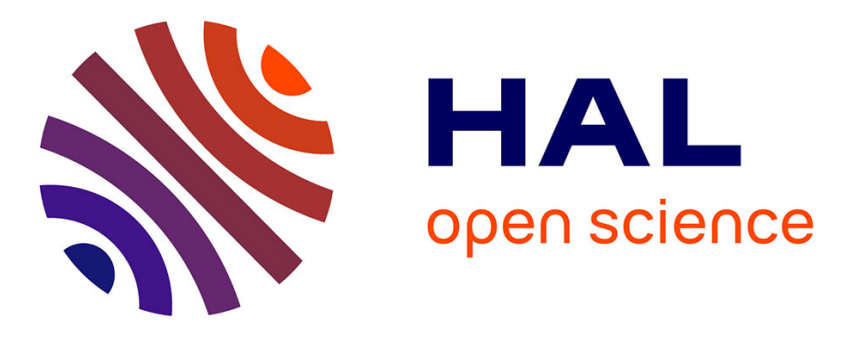

\title{
Radiation-induced reactive oxygen species partially assemble neutrophil NADPH oxidase
}

Stephenson B Owusu, Elodie Hudik, Céline Férard, Sophie Dupré-Crochet, Eric C D K Addison, Kwasi Preko, Tania Bizouarn, Chantal Houée-Levin, Laura Baciou

\section{To cite this version:}

Stephenson B Owusu, Elodie Hudik, Céline Férard, Sophie Dupré-Crochet, Eric C D K Addison, et al.. Radiation-induced reactive oxygen species partially assemble neutrophil NADPH oxidase. Free Radical Biology and Medicine, 2021, 164, pp.76-84. 10.1016/j.freeradbiomed.2020.12.233 . hal-03319583

\section{HAL Id: hal-03319583 https://hal.science/hal-03319583}

Submitted on 12 Aug 2021

HAL is a multi-disciplinary open access archive for the deposit and dissemination of scientific research documents, whether they are published or not. The documents may come from teaching and research institutions in France or abroad, or from public or private research centers.
L'archive ouverte pluridisciplinaire HAL, est destinée au dépôt et à la diffusion de documents scientifiques de niveau recherche, publiés ou non, émanant des établissements d'enseignement et de recherche français ou étrangers, des laboratoires publics ou privés. 
Radiation-induced reactive oxygen species partially assemble neutrophil NADPH oxidase

Stephenson B. Owusu ${ }^{1,2}$, Elodie Hudik ${ }^{1}$, Céline Férard ${ }^{1}$, Sophie Dupré-Crochet ${ }^{1}$, Eric C. D. K. Addison ${ }^{2,3}$, Kwasi Preko ${ }^{2}$, Tania Bizouarn ${ }^{1}$, Chantal Houée-Levin ${ }^{1}$, Laura Baciou ${ }^{1 *}$

${ }^{1}$ Institut de Chimie Physique UMR 8000, CNRS, Université Paris-Saclay, 91405 Orsay Cedex, France

${ }^{2}$ Department of Physics, Kwame Nkrumah University of Science and Technology, Kumasi, Ghana

3 Medical Physics Department, Oncology Directorate, Komfo Anokye Teaching Hospital, Kumasi, Ghana

* Corresponding author:

Email: laura.baciou@universite-paris-saclay.fr

Author Contributions: SBO performed research; EH contributed for cytometry experiments; $\mathrm{CF}, \mathrm{SD}$ and TB contributed to cell purification/analytic tools; ECDK and KP partly supervised the experiments; SBO, CHL and LB designed research and wrote the paper

The authors declare no competing interest

\section{Highlights}

- Gamma irradiation, mimicking oxidative stress, triggers neutrophil priming

- In the absence of any other stimulation, irradiated neutrophils generate moderate amount of ROS through the activation of NADPH oxidase

- ROS production is due to incomplete assembly of the NADPH oxidase complex at the plasma membrane of irradiated neutrophils

- A priming marker was identified on p47 (phosphorylation of Ser345)

- Pre-stimulated neutrophils by irradiation respond with increased oxidative burst 


\begin{abstract}
Neutrophils are key cells from the innate immune system that destroy invading bacteria or viruses, thanks mainly to the non-mitochondrial reactive oxygen species (ROS) generated by the enzyme NADPH oxidase. Our aim was to study the response of neutrophils to situations of oxidative stress with emphasis on the impact on the NADPH oxidase complex. To mimic oxidative stress, we used gamma irradiation that generated $\mathrm{ROS}\left(\mathrm{OH}^{*}, \mathrm{O}_{2}{ }^{--}\right.$and $\left.\mathrm{H}_{2} \mathrm{O}_{2}\right)$ in a quantitative controlled manner. We showed that, although irradiation induces shorter half-lives of neutrophil (reduced by at least a factor of 2), it triggers a pre-activation of surviving neutrophils. This is detectable by the production of a small but significant amount of superoxide anions, proportional to the dose ( $(3$ times that of sham). Investigations at the molecular level showed that this ROS increase was generated by the NADPH oxidase enzyme after neutrophils irradiation. The NADPH oxidase complex undergoes an incomplete assembly which includes $\mathrm{p} 47^{\text {phox }}$ and p67 $7^{\text {phox }}$ but excludes the G-protein Rac. Importantly, this irradiation-induced pre-activation is capable of considerably improving neutrophil reactivity. Indeed, we have observed that this leads to an increase in the production of ROS and the capacity of phagocytosis, leading to the conclusion that radiation induced ROS clearly behave as neutrophil primers.
\end{abstract}

Keywords: Neutrophils; NADPH oxidase; Superoxide radical; ROS; Ionizing radiation.

Abbreviations: AMPK, 5' AMP-activated protein kinase, BCA, bicinchoninic acid; CAPS, Ncyclohexyl-3-aminopropanesulfonic acid; cytb558, cytochrome $b_{558}$; DDM, n-Dodecyl-betaMaltoside; DPI, Diphenyleneiodonium; ECL, enhanced chemiluminescence; GM-CSF, granulocyte-microphage colony-stimulating factors; PMA, phorbol myristic acetate; PMSF, phenylmethylsulfonyl fluoride; ROS, reactive oxygen species; SOD, superoxide dismutase; TBST, tris-buffered saline supplemented with $0.1 \%$ tween; TNF, tumor necrosis factor; PKC, protein kinase $\mathrm{C}$, MAPK, mitogen-activated protein kinase. 


\section{Introduction}

Among the circulating white blood cells, polymorphonuclear neutrophils (PMN) are the most abundant and are crucial players in the innate immune response to severe injury and trauma [1]. Upon infection, activated neutrophils engulf microorganisms (pathogens) into phagosomes, in which a number of cytotoxic and microbicidal agents are released to destroy them $[2,3]$. Among these deleterious agents, the so-called reactive oxygen species (ROS) such as $\bullet \cdot \mathrm{OH}, \mathrm{H}_{2} \mathrm{O}_{2}$, and subsequent oxidants such as $\mathrm{HOCl}$, ONOO- originate from the disproportionate of the primary product $\mathrm{O}_{2}{ }^{--}$massively produced by the NADPH oxidase [4].

The NADPH oxidase is a multi-protein complex constituted with two membrane proteins namely gp91 ${ }^{\text {phox }}$ (also called Nox2) and p22 ${ }^{\text {phox }}$, forming the flavocytochrome $b_{558}$ (cyt $\left.b_{558}\right)$ and four regulatory proteins $\mathrm{p} 47^{\text {phox }}, \mathrm{p} 67^{\text {phox }}, \mathrm{p} 40^{\text {phox }}$ and a G-protein of the Rho family (Rac1/2). This complex can undertake resting, primed and activated states [5]. In resting state, as found in circulating blood neutrophils, the membrane catalytic core of the complex - the so-called flavocytochrome $b_{558}$ (cyt $b_{558}$ )- is localised at the membranes (mainly at the granule membrane) while regulatory proteins are located in the cytosol [3, 6-8]. In such unstimulated neutrophils, Rac is maintained in a GDP-bound cytoplasmic complex dimerized with GDI [9] and the p40 ${ }^{\text {phox }}$, $\mathrm{p} 47^{\text {phox }}$ and $\mathrm{p} 67^{\text {phox }}$ subunits interact in the cytosol in a trimeric complex $[10,11]$. The primed state of NADPH oxidase is induced by a neutrophil pre-stimulation by diverse stimuli such as adhesion neutrophils and pro-inflammatory cytokines (as TNF $\alpha$ and GM-CSF). There are multiple signal transduction pathways that participate in cytokine-induced PMN priming [12]. Most of the priming agents activate the MAPK family or ERK1/2 that partially phosphorylate $\mathrm{p} 47^{\text {phox }}$ (Ser-345) [13-16]. This pre-activation leads to either a very weak or no ROS production but contribute to the regulation of the NADPH oxidase components especially p $47^{\text {phox }}$ p $67^{\text {phox }}$ p40 ${ }^{\text {phox }}$ complex.

Then a secondary stimulus (this stimulating agent can be a pathogen or a pathogen-derived formylated peptides) induces the activation of the NADPH oxidase. This active state results from multiple phosphorylation of $\mathrm{p} 47^{\text {phox }}$ (PKC, MAPK...) leading to translocation of the cytosolic proteins to the membrane cyt $b_{558}[6,7,17]$. This assembly on phagosomal membrane allows the hyper activation of the enzyme and leads to a robust production of ROS, the so-called oxidative burst, allowing effective elimination of pathogens during phagocytosis..

When the active complex assembles at the plasma membrane, ROS are produced extracellularly. This occurs when neutrophils are stimulated by inflammation mediators. PMN secrete into the extracellular medium pro-inflammatory cytokines, proteases and ROS [18]. This extracellular secretion of ROS contributing to inflammation is harmful to the surrounding tissues [19]. Resolution of inflammation and tissue repair occur via a complex cooperation between neutrophils and macrophages where the ROS produced by neutrophils have a paracrine action on macrophage by promoting activation of AMPK in macrophages [20]. Yet, aggregation of neutrophils within infected tissues [21], as it was shown on in lung inflammation tissues [22, 23] can cause an excess inflammation associated to severe tissue damages ([24, 25] and references therein). This situation was very recently pointed out in acute respiratory syndrome coronavirus disease 2019 (COVID-19)[26]. In this situation it was suggested that ROS produced massively could have a paracrine action on the neutrophils themselves by contributing to the NADPH 
oxidase activation [27]. In previous work, we have shown that in vitro the NADPH oxidase complex showed significant sensitivity to the reactive forms of oxygen produced by the gamma irradiation or by hydrogen peroxide as long as the complex was not assembled at the membrane $[28,29]$. Our result suggested that there is a possible negative feedback loop arising from a hyperstimulation of NADPH oxidase that needs to be clarified at the cellular level. Indeed it is not known whether neutrophils are the drivers of the inflammatory storm or the targets.

Thus besides endogenous ROS such as those from mitochondria and other cells leading to intracellular oxidative stress [30], neutrophils are continuously exposed to ROS produced by themselves or to exogenous ROS from surrounding activated PMN. Our objective was to understand how neutrophils react when exposed to oxidative stress i.e. to ROS. Understanding how this feedback loop works has nowadays become a major issue. Besides the fact that neutrophils have been shown to be important in inflammatory diseases, our work finds motivations in medical issues such as the loss of immunity after radiotherapy but also to the risk of transfusion-associated graft versus host disease by irradiation of blood and its components [3137]. Considering our previous in vitro study about the effect of ROS on each components of the enzyme [28, 29], we may speculate that a certain level of the $\mathrm{ROS}\left(\mathrm{OH}^{*}, \mathrm{O}_{2}{ }^{-}\right.$and $\left.\mathrm{H}_{2} \mathrm{O}_{2}\right)$ might mediate alterations on the neutrophil NADPH oxidase. To mimic ROS production we used ionizing radiation that presents several advantages: i) ionizing radiation acts on aqueous solutions by destroying water molecules and creating $\mathrm{ROS}\left(\mathrm{OH}^{*}, \mathrm{O}_{2}{ }^{--}\right.$and $\left.\mathrm{H}_{2} \mathrm{O}_{2}\right)$. Aerated aqueous media is encountered in extra (outside the cell) and intracellular (cytosol) space; ii) the quantity formed of each species is known, hence the results are quantitative; iii) only the products resulting from ROS reactions remain in the irradiated medium [38]. Our work has shown that neutrophil exposure to ROS can act as a stimulus inducing a priming effect on cells and lead to a preactivated state of NAPH oxidase, ready to generate increased oxidative stress.

\section{Materials and Methods}

\section{Purification of neutrophils}

Neutrophils from human peripheral blood from healthy donors (EFS, Cabanel, France) were isolated as described in [39] and more recently in [40], slightly modified from [41]. The method has been adapted to allow neutrophil isolation, irradiation and, if necessary, purification of the membrane fraction in the same day. Briefly, neutrophils were isolated by using $2 \%$ dextran precipitation, followed by a centrifugation at $400 \mathrm{x} \mathrm{g}$ for 8 minutes at room temperature. Mononuclear cells were removed by a Ficoll gradient separation and centrifugation at $400 \mathrm{x} g$ for 30 minutes at room temperature. Two successive hypotonic lysis allowed eliminating contaminating erythrocytes while keeping the neutrophils intact and non-activated. Finally, pellets of purified neutrophils were resuspended in PBS (Dulbecco). Cell viability after isolation was $>98 \%$, as determined by trypan blue exclusion assay. Cell concentration was determined by manually counting using a haemocytometer at a magnification of $400 \mathrm{x}$ under light microscope. Classically, $10^{9}$ neutrophils are isolated from $400 \mathrm{~mL}$ of human blood.

The $\gamma$-irradiation of the neutrophils was carried out using the panoramic ${ }^{60}$ Co gamma-source IL60PL Cis-Bio International (France) at the ICP, University Paris-Saclay (Orsay, France). The 
dose rate $(25 \mathrm{~Gy} / \mathrm{min}$ or $5 \mathrm{~Gy} / \mathrm{min}$ ) was determined by Fricke dosimetry. The irradiation was done at room temperature. In cell suspension, the effect of gamma radiation is mainly indirect due to high percentage of water. The following species are formed: $\mathrm{e}_{\mathrm{aq}}{ }^{-}, \mathrm{HO}^{*}, \mathrm{H}^{*}, \mathrm{H}_{2} \mathrm{O}_{2}, \mathrm{H}_{2}, \mathrm{H}_{3} \mathrm{O}^{+}$. In air atmosphere, only $\mathrm{O}_{2} \bullet^{-}$and $\mathrm{HO} \bullet$ radicals with radiolytic yields $(0.34 \mu \mathrm{mol} / \mathrm{J}$ and $0.28 \mu \mathrm{mol} / \mathrm{J})$, are present during irradiation, in addition to $\mathrm{H}_{2} \mathrm{O}_{2}(0.07 \mu \mathrm{mol} / \mathrm{J})$ thanks to the following reactions.

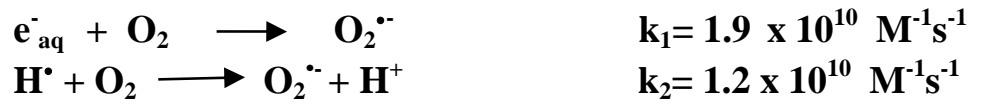

All cell suspensions were irradiated in similar conditions and same cell concentration: $2 \mathrm{~mL}$ neutrophil cell suspension $\left(10^{8}\right.$ cells $\left./ \mathrm{mL}\right)$ were put into a $15 \mathrm{~mL}$ flat cap Falcon tube. One tube was kept as sham (0 Gy). The irradiation time (1-2 min for 25Gy; 2-4 min for 50Gy) was calculated to deliver exactly the required dose. The dose corresponds to 7 and $14 \mu \mathrm{mol} / \mathrm{L}$ of $\mathrm{HO}^{\circ}$ and 8.5 and $17 \mu \mathrm{M}$ of superoxide ions produced respectively in the solution. Another dose rate of $5 \mathrm{~Gy} / \mathrm{min}$ was also tested for the $50 \mathrm{~Gy}$ irradiation dose with an exposure of the sample during 10 minutes (*50 Gy; eq. $14 \mu \mathrm{mol} / \mathrm{L}$ of $\mathrm{HO}^{\circ}$ and $17 \mu \mathrm{M} \mathrm{O}_{2}{ }^{*}$ ). These above mentioned species do not accumulate but react fast and are therefore at a quasi-steady state. Experiments were done in triplicates or more. After each irradiation, dead cell exclusion was achieved by spinning the cells at $400 \mathrm{x}$ g for 8 minutes and verified by trypan blue exclusion assay. Cells were suspended in 2 $\mathrm{mL}$ of PBS and divided equally. Assessment of neutrophil survivals was made after incubation 10 min in Trypan blue dye. Neutrophils that did not take up trypan blue were counted as surviving cells [42]. Cell counting was performed using the trypan blue exclusion assay before irradiation and $1,3,5$ and 15 hours after irradiation.

\section{Phagocytosis assay}

In a subset of experiments, isolated (irradiated) neutrophils were used for phagocytosis assay. In

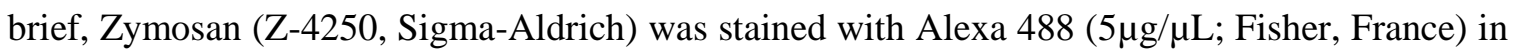
the presence of carbonate buffer at $37{ }^{\circ} \mathrm{C}$ for 1 hour, washed three times and resuspended in PBS. $10^{6} / \mathrm{mL}$ opsonized zymosan stained with Alexa 488 were added to the neutrophil suspension $\left(2 \times 10^{5}\right.$ cells $\left./ \mathrm{mL}\right)$. The suspension was mixed gently and put in an incubator at $37{ }^{\circ} \mathrm{C}$. After 30 minutes the phagocytosis was stopped by transferring the cytometry tubes in a cold bath. Phagocytosis was monitored using CyFlowLLflow cytometer (Sysmex Partec, Norderstedt, Germany) by recording the fluorescence intensity. Parallel negative controls without zymosan were also prepared. To measure phagocytic capacity of neutrophils, the fluorescence was quenched with trypan blue. Results were analysed using FlowJo software.

\section{In cellulo ROS detection}

The ROS produced during phagocytosis were detected by chemiluminescence. In brief, $10 \mu \mathrm{g} / \mathrm{mL}$ horseradish peroxidase (Sigma-Aldrich, France) and $10 \mu \mathrm{M}$ luminol based L-012 (Wako Pure Chemical Industries, Japan) were added to the $2 \times 10^{5}$ neutrophil cell suspension in Hank's buffer before the addition of zymosan opsonised with human serum. The chemiluminescence was measured for 2 hours using Hybrid Multi-Mode Microplate Reader, Synergy ${ }^{\mathrm{TM}} \mathrm{H} 1$ (BioTek Instruments, Winoski) luminometer. The ratio of neutrophils to zymosan was 1:5.

The extracellular production of $\mathrm{O}_{2}{ }^{\circ-}$ was detected with a $2 \times 10^{5}$ cells $/ \mathrm{mL}$ suspended in Hank's buffer in a spectrophotometer cuvette in the presence of $80 \mu \mathrm{M}$ of cyt $c$ for $5 \mathrm{~min}$ at $35{ }^{\circ} \mathrm{C}$. The 
total volume of the solution was $1 \mathrm{~mL}$. Neutrophils were activated by PMA (100 ng/mL) and the superoxide anions production rate during 5 minutes was determined from initial rate of reaction at $550 \mathrm{~nm}$ using an extinction coefficient of $21 \mathrm{mM}^{-1} \mathrm{~cm}^{-1}$.

\section{Plasma membrane purification from neutrophils}

Each subset of neutrophils $\left(0,25,50\right.$ and $\left.50^{*} \mathrm{~Gy}\right)$ dedicated to purification of plasma membrane fractions were centrifuged $400 \mathrm{x}$ g for 8 minutes, cell viability ( $>98 \%)$ verified by trypan blue exclusion assay to remove dead cells and resuspended in lysis buffer $(20 \mathrm{mM}$ phosphate buffer, $\mathrm{pH} 7.4,340 \mathrm{mM}$ sucrose, $7 \mathrm{mM} \mathrm{MgSO}_{4}, 0.2 \mathrm{mM}$ leupeptin and 1mM PMSF). The cells were broken by sonication, followed by centrifugation during 15 minutes, at $10,000 \mathrm{~g}$ at $5{ }^{\circ} \mathrm{C}$. This step leads to a pellet containing granules, mitochondria, unbroken cells, and other organelles. The neutrophil membrane fractions were then separated from the cytosolic ones by further centrifugation for 1.5 hour at 200,000 x g, $5{ }^{\circ} \mathrm{C}$. The membrane fraction (usually, ca. $2 \mathrm{mg} / \mathrm{mL}$ ) was re-solubilized in the lysis buffer by a brief sonication and stored at $-80{ }^{\circ} \mathrm{C}$ in aliquots of 50 $\mu \mathrm{L}$ for further use. Aliquots of the cytosolic fraction (supernatant) were also made and stored at $-80^{\circ} \mathrm{C}$. The protein concentrations were determined using Pierce BCA assays. Experiments were done in triplicate or more.

The $\mathbf{c y t} \boldsymbol{b}_{558}$ concentration was quantified from difference absorption spectrum (reduced minus oxidized at wavelengths $427 \mathrm{~nm}$ and $558 \mathrm{~nm}$ ) using the extinction coefficient of $200 \mathrm{mM}{ }^{-1} \cdot \mathrm{cm}^{-1}$ at the Soret band (427 minus $411 \mathrm{~nm}$ ). The difference spectra of reduced (by dithionite) minus oxidized cyt $b_{558}$ was recorded from each neutrophil membrane preparation. The membrane fraction was solubilized in $1 \%$ dodecyl maltoside (DDM) to decrease sample turbidity and to prevent light scattering.

Western blots. The SDS-PAGE was carried out using $8 \%$ to $12 \%$ polyacrylamide resolving gel containing $0.1 \%$ SDS and $5 \%$ stacking gel. The resolved proteins were electro-transferred from acrylamide gel to a nitrocellulose membrane sheets (GE Healthcare) as described in [43]. The assembly was placed in a $20 \mathrm{mM}$ CAPS buffer $\mathrm{pH} 11.0$ containing $10 \%$ methanol. The transfer was carried out cold and stirred for $1 \mathrm{~h}$ at $150 \mathrm{~V} ; 250 \mathrm{~mA}$. The nitrocellulose membrane was incubated for $1 \mathrm{~h}$ in a $2.5 \%$ solution of Bovine Serum Albumin prepared in $20 \mathrm{ml}$ of 1X TBST containing $0.075 \%$ Tween-20 on orbital shaker at room temperature. The sheets were then incubated overnight at $4{ }^{\circ} \mathrm{C}$ with specific monoclonal or polyclonal antibodies: anti-gp91 (antigp91 ${ }^{\text {phox }}$; 54.1; mouse monoclonal, dilution 1:1500; Santa Cruz), anti-p22 (44.1; mouse monoclonal; dilution 1:1500; Santa Cruz); anti-p40 (D-8; mouse monoclonal; Santa Cruz), antip67 (rabbit polyclonal; dilution 1:1000; Sigma Aldrich); Anti-p47 (rabbit polyclonal; dilution 1:1500); Anti-Rac2 (C-11; rabbit polyclonal; dilution 1:1500), anti-Rac1 (ARCO3; Cytoskeleton); anti-p47-P-ser328 and anti-p47-P-ser345 (rabbit) were a kind gift from Dr El Benna). The immune complex was detected with either goat anti-rabbit (dilution 1:15000; Santa Cruz) or goat anti-mouse (dilution 1:15000; Santa Cruz) secondary antibodies conjugate to peroxidase. The bound peroxidase activity was detected by imaging system (PXi, Syngene) using ECL reagents (Prime Amersham). 
Human cytosolic proteins (p47 $7^{\text {phox }}, \mathrm{p} 67^{\text {phox }}$ and Rac) were expressed in Escherichia coli BL21 (DE3) and purified as described in [44]. The protein purity was determined by SDS gel (10\% bistrisNupage, Biorad) using Coomassie brilliant blue and quantified by the gel imaging system (bio imaging PXi, Syngene). The chromatography for protein purification was carried out using ÄKTAprim system and SP-Sepharose Fast-Flow (FF), Q-Sepharose-FF, Glutathione SepharoseFF, and Ni-NTA-Sepharose-FF resins (GE-Healthcare-Bioscience, France). Cis-Arachidonic acid and cytochrome $c$ were purchased from Sigma-Aldrich, France and NADPH from ACROS, France. The plasmids coding for the human cytosolic proteins, pET15b-Hisp67phox, pET15bHisp47phox, pGEX2T-GSTRac1Q61L were provided by Dr Dagher (IBS, Grenoble, France). Hydrogen peroxide was purchased from Fluka.

The in vitro NADPH oxidase activity was measured with purified membrane fractions (4 nM) in the presence or absence of cytosolic proteins (p47 $7^{\text {phox }}, \mathrm{p} 67^{\text {phox }}$ and Rac1Q61L; on average $300 \mathrm{nM}$ each) in PBS solution supplemented with $10 \mathrm{mM} \mathrm{MgSO}_{4}$ in a spectrophotometer cuvette. When cytosolic proteins were added, incubation in the presence of arachidonic acid $(40 \mu \mathrm{M})$ for $5 \mathrm{~min}$ at $25{ }^{\circ} \mathrm{C}$ was performed. The total volume of the solution was $600 \mu \mathrm{L} .50 \mu \mathrm{M}$ of cyt $c$ and 200 $\mu \mathrm{M}$ of NADPH were then added and the reaction was followed at $550 \mathrm{~nm}$ during $1 \mathrm{~min}$. The production of superoxide anions causes cyt $c$ reduction and thus an increase in absorbance at 550 $\mathrm{nm}$. The activity of NADPH oxidase was computed directly from the initial rate of reaction using the reduced cyt $c$ extinction coefficient of $21 \mathrm{mM}^{-1} \mathrm{~cm}^{-1}$. Control experiments were performed in the presence of $50 \mu \mathrm{g} / \mathrm{mL}$ SOD (Figure S1).

\section{Statistical analysis}

All data are presented as mean \pm SEM. Significance was determined using Student's t test or Repeated Measures ANOVA. A p-value of $\leq 0.05$ was considered statistically significant.

\section{Results}

\section{Cell survival}

The neutrophil purification procedure used consists in layering blood, after dextran sedimentation, over the density gradient medium, centrifugation, separation of neutrophil layer, and lysis of residual erythrocytes. This procedure has been shown to yield samples of $>95 \%$ neutrophils with $>98 \%$ viability [45]. Freshly isolated neutrophils $\left(2 \times 10^{8}\right.$ cells $\left./ \mathrm{mL}\right)$ from healthy donors were irradiated at different doses: $25 \mathrm{~Gy} / 7 \mu \mathrm{M} \mathrm{OH}^{*}, 50 \mathrm{~Gy}$ or $* 50 \mathrm{~Gy} / 14 \mu \mathrm{M} \mathrm{OH}^{*}$. 1, 3, 5 and 15 hours after irradiation. Dead cells were then eliminated by centrifugation. Each irradiated cell suspension was divided into two equal volumes, one for ROS production assays and phagocytosis experiment and the other one for counting under light microscope, using trypan blue exclusion assay, at successive times after irradiation. During the counting, cells were kept at room temperature. Surviving neutrophils were counted based on their ability to exclude trypan blue. As 
shown in Figure 1, the number of both non-irradiated and irradiated neutrophils decreased exponentially with time. The rate of cell death increased initially with dose and reached a plateau in the subsequent hours ca. 2 hours. This indicates that the radiosensitive neutrophil population were dead within 2 hours while the remaining ones tend to be resistant (Figure 1). Using the exponential parameters of the fits in Figure 1, lifetimes of the neutrophils were then calculated (Table 1). From Table 1, the half-life of the neutrophils decreased accordingly as we increased the dose of irradiation. While the non-irradiated sample retained half of the cells up until 2 and half hours, about half of the cells were dead within the first 1 hour post 50 Gy irradiation. Meanwhile, half of the cells irradiated at 25 Gy were able to withstand this dose for 2 hours.

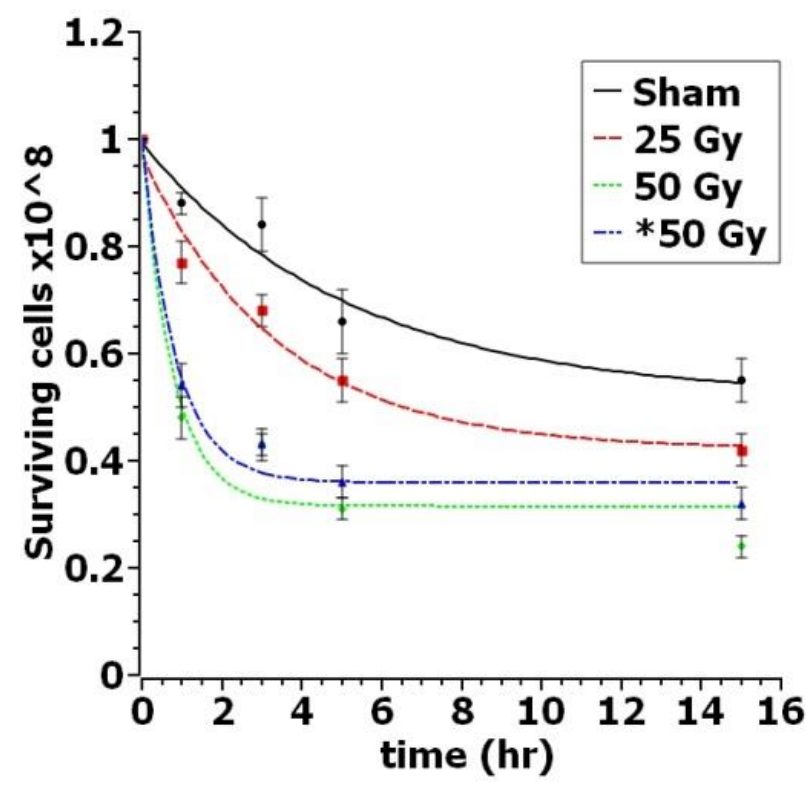

Figure 1: Effect of irradiation on neutrophil survival. neutrophils from healthy donors $\left(2 \times 10^{8}\right.$ cells $/ \mathrm{mL}$ ) were irradiated at doses $25 \mathrm{~Gy}, 50 \mathrm{~Gy}$ and $* 50 \mathrm{~Gy}$. After irradiation, the cells were counted under light microscope. Trypan blue was used to distinguish surviving cells from dead cells. Surviving cells are the number of living cells counted post irradiation. The data were fitted with monoexponential functions.

Table 1: Post-irradiation half-lives of neutrophils. The values were obtained by exponential fitting of survival cell curves (Fig. 1).

\begin{tabular}{|c|c|c|}
\hline $\begin{array}{c}\text { Dose } \\
(G y)\end{array}$ & $\begin{array}{c}\mu \mathrm{mol} / \mathrm{L} \text { of } \\
\text { HO• }\end{array}$ & $\begin{array}{c}\text { Half-life of neutrophils } \\
\pm \mathbf{1 5 \%} \text { (minutes) }\end{array}$ \\
\hline 0 & 0 & 138 \\
\hline
\end{tabular}




\begin{tabular}{|c|c|c|}
\hline 25 & 7 & 114 \\
\hline 50 & 14 & 24 \\
\hline$* 50$ & 14 & 24 \\
\hline
\end{tabular}

The in vitro half-life of resting non-irradiated PMN was estimated to 2.3 hours (138 minutes). As expected, this value decreased by increasing the dose of irradiation. It means that in the nonirradiated sample, half of the cells are surviving until two and half hours but in the irradiated sample, half of the cells were dead within the first 1 hour post irradiation. No significant difference was observed with different dose rates (*50 Gy versus $50 \mathrm{~Gy}$ ).

\section{In cellulo analysis of irradiated neutrophils}

Using chemiluminescence assay, we determined the total amount of ROS produced by the irradiated and non-irradiated neutrophils over 2 hours (Figure 2A). This technique detects extracellular ROS that can be generated inside or outside cells [46]. Importantly, we normalized the data by the number of cells estimated from the survival curves.
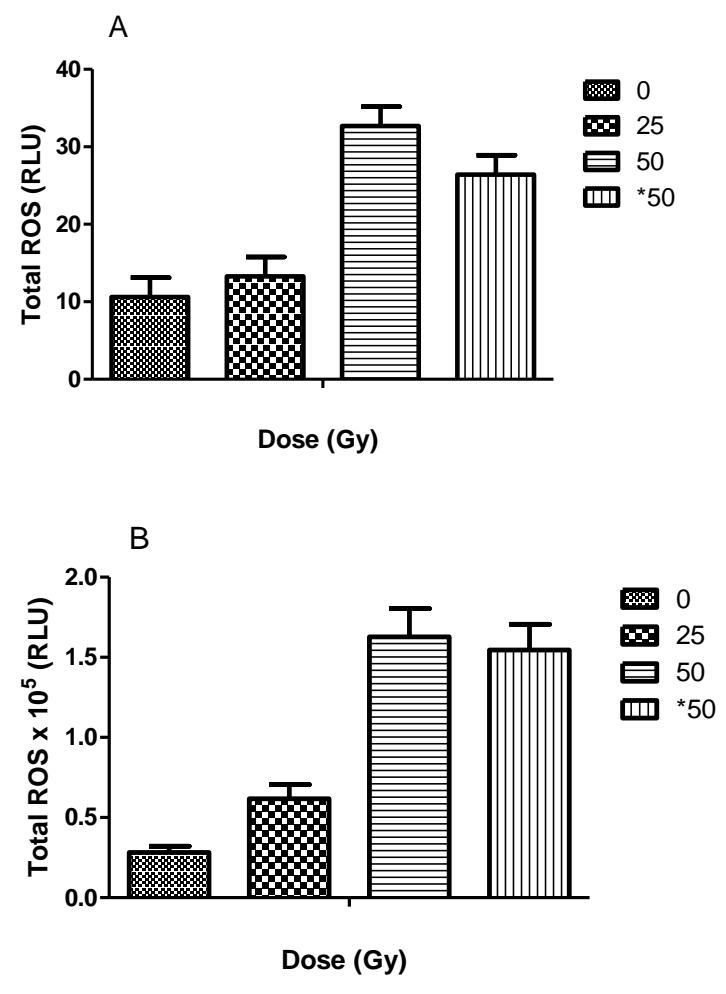

C 


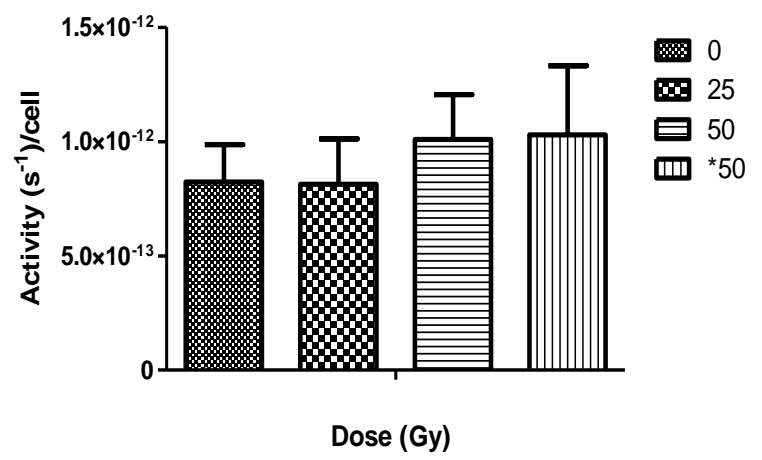

Figure 2. Irradiation effect on neutrophils ROS production: A. by unstimulated neutrophils. ROS produced by unstimulated neutrophils after irradiation were detected by chemiluminescence generated by the reaction of HRP and L-012 (see materials and methods). The area under chemiluminescence curve (Total ROS) was calculated using Excel software B. By phagocytosing neutrophils. Neutrophils were allowed to phagocyte zymosan opsonized with human serum for 2 hours, and the ROS production was determined by the chemiluminescence generated by the reaction of HRP and luminol base L-012 (Fig. S2). The ratio of neutrophils to opsonised zymosan was 1:5. The area under chemiluminescence curve (Total ROS) was directly computed by the luminometer. C. By neutrophils after PMA stimulation: Neutrophils were activated by PMA (100 ng/mL) and the superoxide anions production during 5 minutes was indirectly quantified from cytochrome c (80 $\mu \mathrm{M})$ reduction at $550 \mathrm{~nm}$ using spectrophotometry. Data are mean \pm SEM of 3 independent experiments

Non-irradiated or 25 Gy-irradiated PMN induced only weak responses of neutrophils while the 50 Gy-irradiation increased by about 2-3 times the amount of ROS generated by the PMN. Thus without any other activator, irradiation induced an increase of the generated ROS by neutrophils, indicating that free radicals constitute a stimulus of resting PMN.

We further measured the production of ROS by zymosan-phagocytosing neutrophils (Figure 2B). We observed that the ROS produced by irradiated phagocytosing PMN is higher than that produced by non-irradiated cells. The increase is noticeable for $25 \mathrm{~Gy}$ irradiated PMN and is even more significant (x 5) for cells irradiated with 50 Gy (whatever the dose rate). Thus the increase appears to be dose dependent. We determined also the phagocytic index (Table 2) and we observed that the phagocytic activity increased as well for irradiated cells in a dose dependent manner.

Table 2: Phagocytic capacity of neutrophils. Phagocytic activity of neutrophils is expressed as phagocytic index $(\mathrm{PI})=(\%$ phagocytic cells containing $\geq 1$ zymosan $) \times$ (mean number of zymosan/phagocytic cell). Number of donors $=2$.

\begin{tabular}{|c|c|}
\hline Dose (Gy) & Phagocytic Index \\
\hline $\mathbf{0}$ & $508.7 \pm 261.8$ \\
\hline $\mathbf{2 5}$ & $641.7 \pm 19.8$ \\
\hline $\mathbf{5 0}$ & $675.3 \pm 177.3$ \\
\hline
\end{tabular}


Finally we determined the quantity of superoxide ions produced extracellularly by neutrophils after stimulation with PMA. A slight increase could be observed but due to a limit of the significance, we cannot conclude that there is a significant increase of superoxide production rate for irradiated cells compared to sham (Figure 2C).

Taken as a whole, our analyses of cell behaviors show that irradiation stimulated the resting neutrophils resulting in a production of ROS. Also the oxidative burst level and the phagocytic capacity of irradiated PMN were boosted.

\section{In vitro analysis of irradiated neutrophils}

Further we aim to appreciate the implication of the NADPH oxidase in the increase of ROS production that was observed in irradiated cells. For this purpose, we isolated the membrane fractions of the living neutrophils after their irradiation.

By spectrophotometry, we determined the concentration of cyt $b_{558}$ at the membrane fractions by dithionite-reduced minus oxidized difference absorption. The characteristic heme peaks at $427 \mathrm{~nm}$ (Soret band) and $558 \mathrm{~nm}$ was found similar for membrane fractions isolated from irradiated and non-irradiated neutrophils and did not display any particular changes or shifts (Figure 3). This suggests that ionizing radiation did not modify the prosthetic group and its close environment.
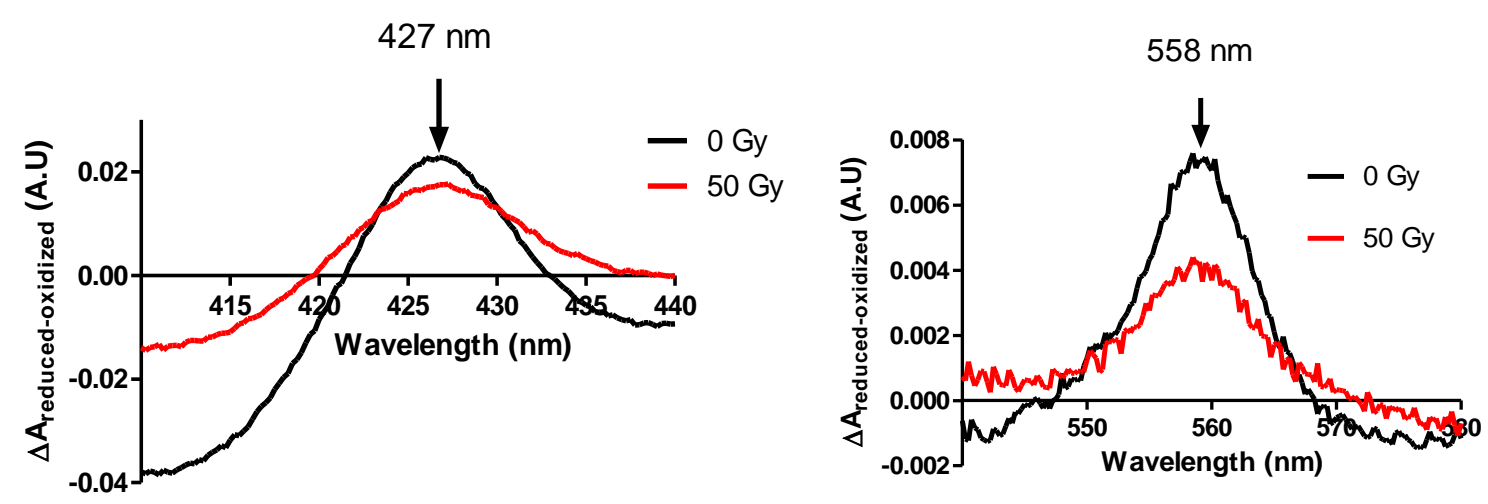

Figure 3. Characterization of cytb $_{558}$ in membrane fractions from irradiated and nonirradiated neutrophils: difference absorption spectra of $\mathbf{c y t b}_{\mathbf{5 5 8}}$. The membrane fractions from surviving cells were solubilised in $1 \%$ DDM. The amount of cyt $b_{558}$ is determined from the difference absorption spectra of the redox protein in its dithionite-reduced minus oxidized form. The reduced form is obtained by adding $1 \mathrm{mg}$ of sodium dithionite.

To be sure about the concentration of cyt $b_{558}$ for enzyme activity assays, we needed to statistically demonstrate the consistency of the protein level in different samples. This implies the need to provide reliable quantitative data on the amount of cyt $b_{558}$ from the spectrophotometric approach. Thus, the concentration of cyt $b_{558}$ estimated by spectrophotometry was subsequently re-probed with antibody against gp91 $1^{\text {phox }}$ and $\mathrm{p} 22^{\text {phox }}$ proteins (Figure S3). We also performed 
BCA assays to determine total membrane protein concentration in each sample and deduced the amount of cyt $b_{558}$ per total membrane proteins in cells (Table 3). Our data show that the cyt $b_{558}$ per total membrane per cell increased in a dose dependent manner.

Table 3: Content of $c y t b_{558}$ in plasma membrane per cell. The amount of cyt $b_{558}$ in plasma membrane isolated from irradiated and non-irradiated neutrophils were determined from the spectra peak height $(411 \mathrm{~nm}$ to $427 \mathrm{~nm}$ in Figure 2). the result was divided by the total membrane protein quantity determined by performing BCA assays of each plasma membrane fractions and finally by the total number of living cells.

$\begin{array}{cc}\text { Dose (Gy) } & \text { mg of } \mathbf{c y t b}_{558} / \mathrm{mg}_{\text {of }} \text { total membrane proteins } * 10^{-9} / \text { cell } \\ 0 & 0.8 \pm 0.2 \\ 25 & 0.7 \pm 0.2 \\ 50 & 1.8 \pm 0.4 \\ * 50 & 2.2 \pm 0.7\end{array}$

In vitro, the kinetics of superoxide production by cyt $b_{558}$ was studied in purified membrane fractions from neutrophils using the classical cell free assay approach. This method allows a specific and quantitative detection of superoxide anions. Figure 4 shows the superoxide production generated using the neutrophil membrane fractions with recombinant regulatory proteins but without the activator, arachidonic acid. An increase of superoxide production was observed after irradiation in a dose dependent manner. This activity was inhibited by the inhibitor of NADPH oxidase, diphenyliodonium (DPI) (Figure S4). Similar to the increase of in cellulo generated ROS by irradiated neutrophils, this in vitro behaviour is consistent with the idea of the presence of functional NADPH oxidases. This result is consistent with the increase of ROS production observed after irradiation of unstimulated neutrophils (Figure 2A).

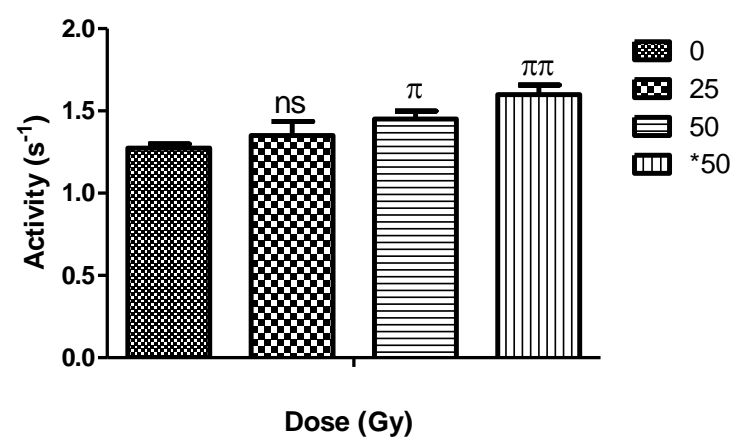

Figure 4: Irradiation effect on specific activity of NADPH oxidase in membrane fractions from irradiated and non-irradiated neutrophils. Membrane fractions containing $4 \mathrm{nM}$ cyt $b_{558}$ mixed with recombinant cytosolic proteins (averagely $300 \mathrm{nM}$ each of $\mathrm{p} 47^{\text {phox }}, \mathrm{p} 67^{\text {phox }}$ and Rac1) were incubated in PBS buffer supplemented with $10 \mathrm{mM} \mathrm{MgSO}_{4}$ for 5 minutes at $25{ }^{\circ} \mathrm{C}$. To $200 \mu \mathrm{M}$ of NADPH were added to initiate the reaction after addition of $50 \mu \mathrm{M}$ of cyt $c$. superoxide production was indirectly measured 
from initial rate of reaction at $550 \mathrm{~nm}$ using an extinction coefficient of $21 \mathrm{M}^{-1} \mathrm{~cm}^{-1}$. Data are mean \pm SEM of 3 or more independent experiments. ${ }^{\pi} p<0.05,{ }^{\pi \pi} p<0.01$, ns means non-significant.

To explain the increased in vitro ROS production (since we put the same enzyme concentration from each subset), we deciphered more in depth the composition of the NADPH oxidase components in the isolated membrane fractions using Western blot analyses. Physiologically, the functional active enzyme is known to aggregate as a complex constituted with at least the four following cytosolic proteins, $\mathrm{p} 47^{\text {phox }}, \mathrm{p} 67^{\text {phox }}, \mathrm{p} 40^{\text {phox }}$ and Rac attached to the membrane partner gp9 $1^{\text {phox }}$ and $\mathrm{p} 22^{\text {phox }}$. As shown in Figure 5, the presence of the regulatory proteins $\mathrm{p} 67^{\text {phox }}$, $\mathrm{p} 40^{\text {phox }}$ and $\mathrm{p} 47^{\text {phox }}$ was detected associated to the membrane of irradiated neutrophils. The intensities of the signals increased with the dose suggesting that the presence of these proteins at the neutrophil membranes increased with radiation dose. In contrast, even for the higher dose, no signal was detected for either Rac1 or Rac2 suggesting that these proteins did not respond in the same way to the irradiation-induced ROS.

A

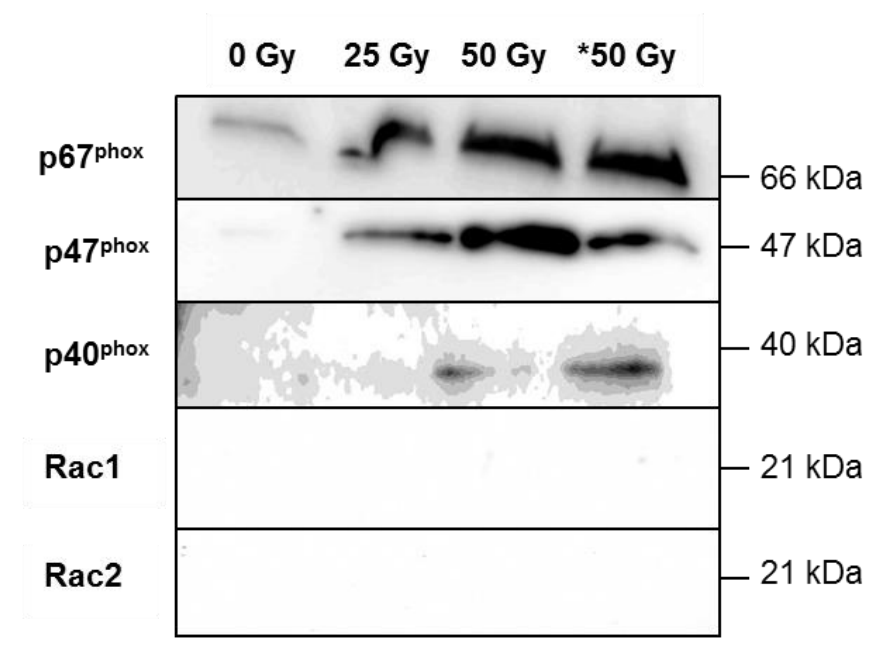

B

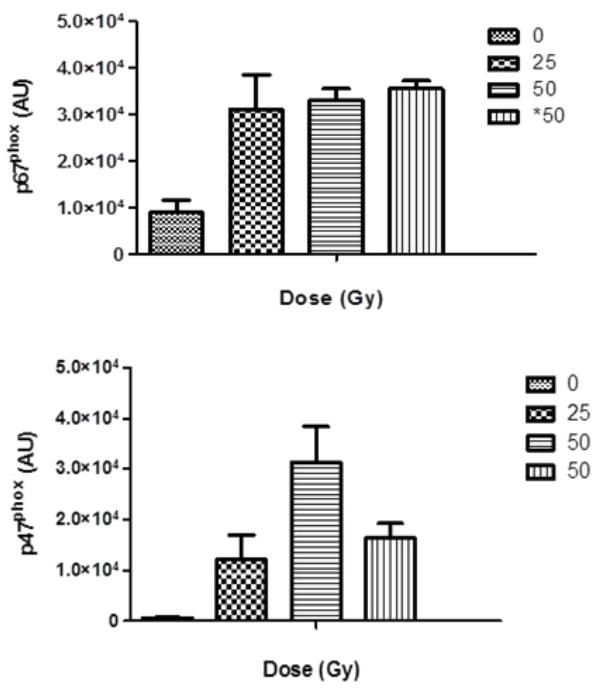

Figure 5: Western blot analysis of membrane fractions isolated from irradiated and nonirradiated cells. A. Western blot of the membrane fractions of both irradiated and nonirradiated neutrophils were performed using specific antibodies against cytosolic proteins $\mathrm{p} 67^{\text {phox }}, \mathrm{p} 40^{\text {phox }}, \mathrm{p} 47^{\text {phox }}$, Rac1 and Rac2. Lane 1, Sham (non-irradiated neutrophils), lane 2, 3 and 4 represent neutrophils irradiated at $25 \mathrm{~Gy}, 50 \mathrm{~Gy}$ and $* 50 \mathrm{~Gy}$ respectively. Each lane contained the same amount $\left(1 * 10^{-6} \mu \mathrm{mol}\right)$ of cyt $b_{558}$ and was incubated with antibodies against indicated protein. B. intensity of western blot of $\mathrm{p} 47^{\text {phox }}$ (bottom) and $\mathrm{p} 67^{\text {phox }}$ (top) were quantified by densitometry using ImageJ software. Results are representative of 3 independent experiments.

Our results indicate that radiation-induced ROS triggered specifically the translocation of the regulatory subunits $\mathrm{p} 67^{\text {phox }}, \mathrm{p} 40^{\text {phox }}$ and $\mathrm{p} 47^{\text {phox }}$ in a dose dependent manner. Similar effect was 
observed for neutrophils treated with hydrogen peroxide where $\mathrm{p} 47^{\text {phox }}$ was also found at the membrane (Fig. S5).

Since translocation to the membrane is driven mainly by phosphorylated $\mathrm{p} 47^{\text {phox }}$, we investigated its phosphorylation state. By using antibodies against phosphorylated $\mathrm{p} 47^{\text {phox }}$, we could highlight that $\mathrm{p} 47^{\text {phox }}$ was phosphorylated at Serine ${ }^{345}$, but no signal was detected for the phosphorylated Serine ${ }^{328}$ (Figure 6). One can notice that the cytosolic fractions isolated from irradiated cells did not show any phosphorylation state, neither Serine ${ }^{328}$ nor Serine ${ }^{345}$ (data not shown). This indicates that the phosphorylation of Serine 345 was sufficient and necessary for the translocation of the hetero-trimer $\mathrm{p} 47 \mathrm{phox} / \mathrm{p} 67 \mathrm{phox} / \mathrm{p} 40^{\text {phox }}$ at the membrane. Phosphorylation of Serine $\mathrm{e}^{345}$ constitutes the hallmark of the molecular signature of neutrophil irradiation.

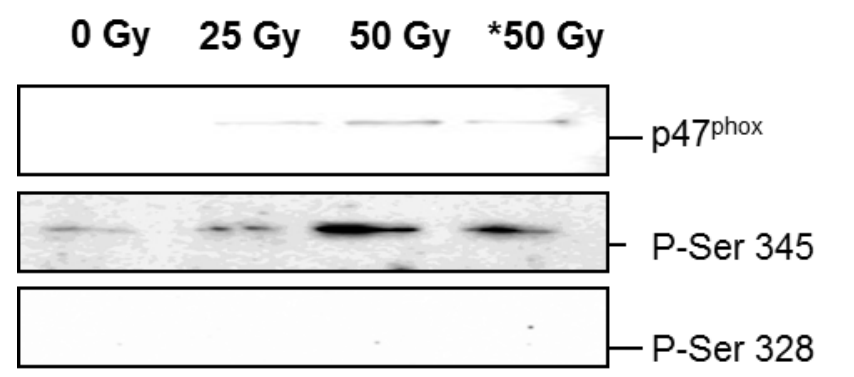

Figure 6: Lane 1, Sham, lane 2, 3 and 4 represent neutrophils irradiated at 25 Gy, 50 Gy and $* 50$ Gy respectively. Each lane contains $20 \mu \mathrm{g}$ of each membrane protein, incubated with a primary antibody for $\mathrm{p} 47^{\text {phox }}, \mathrm{p}$-serine $\mathrm{s}^{345}$ and $\mathrm{p}$ $\operatorname{serine}^{328}$..

Ultimately, we used the canonical cell-free assay to reconstitute the NADPH oxidase complex in vitro. For this purpose we used the membrane fractions purified from irradiated and nonirradiated neutrophils together with recombinant cytosolic proteins. After incubation with the well-known activator arachidonic acid, we observed that the specific activities generally had higher values compared to those without activator. However, the activities determined with membrane fractions from irradiated neutrophils decreased slightly compared to that from nonirradiated one (Figure 7). This observation is the opposite of in vivo experiments (Figure 2C) and could be attributed to the different nature of the stimulus in the two experiments. It is also possible that it is related to an optimal concentration of arachidonic acid modified in the cell-free assays after cell irradiation or to other phenomena such as possible negative regulation by $\mathrm{p} 40^{\text {phox }}$ that remain to be elucidated. 


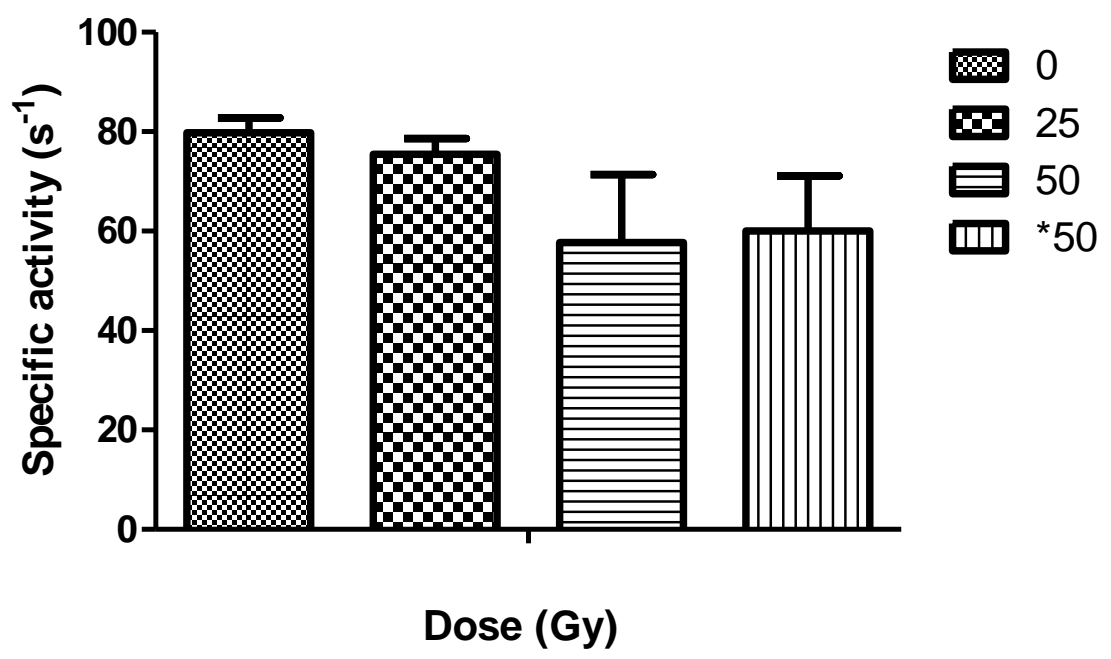

Figure 7: Specific activity of NADPH oxidase from irradiated and non-irradiated neutrophils. Superoxide production was determined in vitro using membrane fractions (4 $\mathrm{nM}$ cyt $b_{558}$ ) purified from irradiated and non-irradiated surviving neutrophils mixed with recombinant cytosolic proteins (averagely $300 \mathrm{nM}$ each of $\mathrm{p} 47^{\text {phox }}, \mathrm{p} 67^{\text {phox }}$ and Rac1) and incubated in activity buffer (PBS solution supplemented with $10 \mathrm{mM} \mathrm{MgSO}_{4}$ ) for 5 minutes in the presence of AA $(40 \mu \mathrm{M}) .200 \mu \mathrm{M}$ of NADPH was added to initiate reaction and $50 \mu \mathrm{M}$ of cyt $c$ to measure superoxide rate of production. The activity was calculated from initial rate of reaction at $550 \mathrm{~nm}$ using an extinction coefficient of $21 \mathrm{M}$ ${ }^{1} \mathrm{~cm}^{-1}$. Specific activity indicates the amount of superoxide produced per second per mole of cyt $b_{558}$ of NADPH oxidase. Data are mean \pm SEM of 3 independent experiments.

\section{Discussion}

In this work we addressed the effect of oxidative stress created by ionizing radiation on unstimulated human neutrophils. Neutrophils are continuously generated in the bone marrow and are at the heart of the human body's innate immune defense system. Blood neutrophils have relatively short half-life. The in vivo circulating half-life of human neutrophils was estimated to range between 4 and 17 hours in peripheral blood [47-50]. To our knowledge, there are no reports on the half-life of neutrophils in vitro, even though the cell-death kinetics have been extensively studied. To estimate the average in vitro half-life, we isolated neutrophils from the blood of healthy donors and measured their survival in vitro. We could estimate the in vitro half-life of about 2.3 hours for isolated neutrophils (sham) which is shorter but close to that described in literature for circulating neutrophils $[47,49]$. The small difference can easily be explained by the different (abnormal) environment and ex vivo manipulation [51-53]. The estimation of half-life values of non-irradiated PMN were a prerequisite for further investigation on the effect of ionizing radiation in survival cells. Neutrophils were irradiated with doses of 25 and 50Gy, which means that they were submitted to $8.5 \mu \mathrm{M} \mathrm{O}_{2}{ }^{\circ-}$ and $6.75 \mu \mathrm{M} \mathrm{OH} \bullet$ free radicals (25 Gy) and to the 
double (17 and $13.5 \mu \mathrm{M} \mathrm{O}_{2}{ }^{\circ-}$ and $\mathrm{OH} \bullet$ free radicals respectively) for $50 \mathrm{~Gy}$. To these free radicals one must add hydrogen peroxide (respectively 1.75 and $3.5 \mu \mathrm{M}$ initially). These species were generated intracellularly and extracellularly during irradiation. Altogether the amount of added radio-induced ROS is close to the ROS produced by neutrophils at steady state in phagosomes (25 $\mu \mathrm{M}$ superoxide and $2 \mu \mathrm{M} \mathrm{H}_{2} \mathrm{O}_{2}$ )[54]. After irradiation, in vitro half-lives of neutrophils decreased in a dose dependent manner, similarly to what was also observed for irradiated red blood cells [55]. The 25 Gy-irradiation affected only slightly the half-life of neutrophils. This result conforms to blood irradiation reports indicating that a minimal gamma irradiation dose of $25 \mathrm{~Gy}$ is required to effectively inactivate lymphocytes in red blood cell units without affecting granulocytes[37]. With the highest dose level (50 Gy), only half of neutrophils are lost one hour after irradiation allowing sufficient materials to investigate more in depth the molecular effect of the radiation-induced ROS.

Importantly, our findings demonstrate that radio-induced ROS stimulated the neutrophils and lead to a priming state of the NADPH oxidase enzyme. This was manifest by the following events.

First our findings demonstrate that irradiated neutrophils produced ROS. Although the ROS amount is low, it is however substantial and occurs in a dose dependent manner. This was observed in cellulo in the absence of any other stimulus, but also in vitro with no addition of AA activator, which is indispensable for superoxide production in cell free assay $([40,56])$. It was shown that TNF $\alpha$ primed AA release in human neutrophils [57-59]. Thus it might be possible that similarly, a radio-induced enhancement of AA release could occur. Second, the amount of cyt $b_{558}$ increased at the plasma membrane. This may occur by degranulation that constitutes one of the characteristics of priming state. It is known that neutrophil activation causes the cyt $b_{558}$ localized in the specific granules in the resting neutrophils, to move to the plasma membrane [1-3]. Up to $50 \mathrm{~Gy}$, no modification of the spectra of cyt $b_{558}$ was observed indicating that the heme structures as well as its environments were not damaged by irradiation. Thirdly, we demonstrated the presence of three $\left(\mathrm{p} 47^{\text {phox }}, \mathrm{p} 40^{\text {phox }}\right.$ and $\mathrm{p} 67^{\text {phox }}$ ) out of four cytosolic proteins at the membrane. In resting state, the components of NADPH oxidase are at separate localizations from the membrane. In normal physiological conditions, the assembly of the cytosolic components to cyt $b_{558}$ in neutrophils is triggered by pro-inflammatory mediators which induce signaling pathways (activation of many kinases) [17, 60], that catalyze the phosphorylation of the cytosolic components, enabling their translocation to the $c y t b_{558}$. [61]. We show here that the radio-induced ROS induced similar effects except that this coincides only with the partial phosphorylation of $\mathrm{p} 47^{\text {phox }}$ on $\operatorname{Ser}^{345}$ known to result from the activation of the MAPK pathway, common event of priming of human neutrophils by TNF- $\alpha[14,62]$. This phosphorylation allowed conformational changes necessary for the attachment of the regulatory proteins at the membrane. Since p $67^{\text {phox }}$ and $\mathrm{p} 40^{\text {phox }}$ cannot translocate by themselves, the presence of $\mathrm{p} 67^{\text {phox }}$ and $\mathrm{p} 40^{\text {phox }}$ at the membrane may have resulted from conformational changes of the $\mathrm{P}-\mathrm{ser}^{345} \mathrm{p} 47^{\text {phox }}$ subunit prompting it to translocate $\mathrm{p} 67^{\text {phox }}$ and $\mathrm{p} 40^{\text {phox }}$ to the membrane. Phosphorylation of $\operatorname{Ser}^{345}$ was suggested to be of critical importance for the priming state of ROS production in neutrophils and being a key element for further $\mathrm{p} 47^{\text {phox }}$ hyper-phosphorylation [16, 63]. It is consistent with preceding findings of activation of kinases by ROS [27]. 
No Rac was detected at the membrane level after irradiation and the absence of Rac did not prevent the production of ROS. Therefore radiation cannot be considered as a stimulus for Rac activation. Indeed in the absence of other stimulation and in the absence of the small Rac GTPase which is likely maintained at the associated inhibitory protein, irradiated neutrophils produce superoxide anions albeit at lower levels, the partially assembled NADPH oxidase complex being active. This is therefore different from the active state of the NADPH oxidase for which in vitro and in vivo consensus studies indicate that Rac is necessary for oxidative burst[17, 61].

Finally, our results demonstrate that the radio-induced ROS activation of neutrophils operates as a pre-triggering. Intracellular superoxide production increases significantly after irradiation when the cells were stimulated by PMA and by opsonized zymosan. This latter increase is possibly linked to that of the phagocytosis capacity and the rate of phagocytosis. In our previous studies, where the membrane fractions isolated from neutrophils and the recombinant cytosolic proteins (p47phox, p67phox and Rac) were irradiated separately, we showed that, at the opposite, irradiation reduced drastically the activity of NADPH oxidase in vitro. Compared to cytosolic proteins, the membrane fractions were the most radiation-sensitive indicating that this radiosensitivity could result from membrane protein modifications and/or lipid peroxidations [29]. Here we observe that the cellular environment ensures enough protection of the Cyt $b_{558}$ against free radicals and instead of being harmful, radio-induced ROS act as a stimulus in the activation processes of the NADPH oxidase driving the enhancement of the oxidative burst. This could be a clue to modulating cellular responses. Ultimately, in blood irradiation, activation of NADPH oxidase in neutrophils may result in multifaceted role due to different compositions that were not explored here since we did not considered neutrophils in the blood context. Plasma and in particular plasma inflammatory milieu are complex media that contain many different cells (monocytes, macrophages,..) and various compounds. In the circulation of healthy adults, neutrophils exist in a resting state, which ensures that their toxic intracellular contents are not accidentally released to damage host tissue. But in inflammatory plasma, neutrophils are in addition exposed to molecules that include bacterial products and cytokines or chemokines that may play with growth factors as major regulators of neutrophil survival. For this reason, in vitro experiments using freshly isolated blood neutrophils may fail to recognize the full functional repertoire and capability of neutrophils.

In conclusion, some years ago it was suggested that ROS could behave as priming agents in addition to cytokines [27, 64]. We highly enlightened here the molecular consequences of neutrophil exposure to radio-induced ROS. More than 25 Gy (eq. $7 \mu \mathrm{M}$ ROS) stimulate neutrophils. This priming effect due to superoxide, $\mathrm{OH} \bullet$ and $/$ or $\mathrm{H}_{2} \mathrm{O}_{2}$, consists of pre-activation of NADPH oxidase by partial assembly and production of superoxide. This pre-activation of NADPH oxidase potentiates its activity leading to an increased production of ROS for the fully assembled enzyme complex. As for blood irradiation above $25 \mathrm{~Gy}$, we show that it can have adverse consequences on the release of ROS from phagocytes. Doses above this threshold can prime neutrophils, which are then more prone to activation and could therefore increase cellular damage due to irradiation. This can lead to subsequent effects on other blood cells as well as on the human immune defense. 
It would be of major importance to identify which ROS did behave as priming agent. We cannot answer directly to this crucial question but we can consider the following facts: i) hydrogen peroxide seems to provoke similar effects to those of irradiation; ii) the reactivity of $\mathrm{OH}$ radicals is so high that it is difficult to imagine targeted effects from theses radicals. Hence one can suggest that the priming may be due to the conjunction of superoxide and hydrogen peroxide.

Understanding how oxidative stress induces an over-activation of neutrophils that is harmful to the organism, has become a problem of major interest today. Accumulation of immune cells at the site of inflammation might increase their exposure to ROS for longer period, that might accelerate the development of the oxidative stress situation. Here we showed that neutrophils exposure to radiation-induced ROS contributes to activating the enzyme. In an inflammation context, it might be possible that inflammation self-potentiates NADPH oxidase activity, like in chain reactions.

\section{Acknowledgments}

This work was supported by grant from Electricité de France (EDF RB 2016-21) and by Centre National de la Recherche Scientifique (CNRS), University Paris Sud, University Paris Saclay and French Government (France Embassy and Campus France, Ghana). The authors also thank Dr. Jamel El Benna for his kindly gift of antibodies against phosphorylated forms of $\mathrm{p} 47^{\text {phox }}$.

\section{References}

1 Kobayashi, S. D. and DeLeo, F. R. (2009) Role of neutrophils in innate immunity: a systems biology-level approach. Wiley Interdisciplinary Reviews-Systems Biology and Medicine. 1, 309-333

2 Segal, A. W. (2005) How neutrophils kill microbes. Annual Review of Immunology. 23, 197-223

3 Hampton, M. B., Kettle, A. J. and Winterbourn, C. C. (1998) Inside the neutrophil phagosome: Oxidants, myeloperoxidase, and bacterial killing. Blood. 92, 3007-3017

4 Bedard, K. and Krause, K. H. (2007) The NOX family of ROS-generating NADPH oxidases: physiology and pathophysiology. Physiol Rev. 87, 245-313

5 Belambri, S. A., Rolas, L., Raad, H., Hurtado-Nedelec, M., Dang, P. M. and El-Benna, J. (2018) NADPH oxidase activation in neutrophils: Role of the phosphorylation of its subunits. Eur J Clin Invest. 48 Suppl 2, e12951

6 Segal, A. W. (2008) The function of the NADPH oxidase of phagocytes and its relationship to other NOXs in plants, invertebrates, and mammals. International Journal of Biochemistry \& Cell Biology. 40, 604-618

7 Babior, B. M., Lambeth, J. D. and Nauseef, W. (2002) The neutrophil NADPH oxidase. Archives of Biochemistry and Biophysics. 397, 342-344 
8 Cachat, J., Deffert, C., Hugues, S. and Krause, K. H. (2015) Phagocyte NADPH oxidase and specific immunity. Clin Sci (Lond). 128, 635-648

9 Bokoch, G. M., Bohl, B. P. and Chuang, T. H. (1994) Guanine-Nucleotide Exchange Regulates Membrane Translocation of Rac/Rho Gtp-Binding Proteins. Journal of Biological Chemistry. 269, 31674-31679

10 Lapouge, K., Smith, S. J. M., Groemping, Y. and Rittinger, K. (2002) Architecture of the p40-p47-p67phox complex in the resting state of the NADPH oxidase - A central role for p67(phox). Journal of Biological Chemistry. 277, 10121-10128

11 Ziegler, C. S., Bouchab, L., Tramier, M., Durand, D., Fieschi, F., Dupre-Crochet, S., Merola, F., Nusse, O. and Erard, M. (2019) Quantitative live-cell imaging and 3D modeling reveal critical functional features in the cytosolic complex of phagocyte NADPH oxidase. J Biol Chem. 294, 3824-3836

12 McLeish, K. R., Knall, C., Ward, R. A., Gerwins, P., Coxon, P. Y., Klein, J. B. and Johnson, G. L. (1998) Activation of mitogen-activated protein kinase cascades during priming of human neutrophils by TNF-alpha and GM-CSF. Journal of Leukocyte Biology. 64, 537-545

13 Hurtado-Nedelec, M., Csillag-Grange, M. J., Boussetta, T., Belambri, S. A., Fay, M., Cassinat, B., Gougerot-Pocidalo, M. A., Dang, P. M. and El-Benna, J. (2013) Increased reactive oxygen species production and p47phox phosphorylation in neutrophils from myeloproliferative disorders patients with JAK2 (V617F) mutation. Haematologica. 98, 1517-1524

14 Dang, P. M., Stensballe, A., Boussetta, T., Raad, H., Dewas, C., Kroviarski, Y., Hayem, G., Jensen, O. N., Gougerot-Pocidalo, M. A. and El-Benna, J. (2006) A specific p47phox -serine phosphorylated by convergent MAPKs mediates neutrophil NADPH oxidase priming at inflammatory sites. J Clin Invest. 116, 2033-2043

15 Bylund, J., Samuelsson, M., Collins, L. V. and Karlsson, A. (2003) NADPH-oxidase activation in murine neutrophils via formyl peptide receptors. Exp Cell Res. 282, 70-77

16 El-Benna, J., Hurtado-Nedelec, M., Marzaioli, V., Marie, J. C., Gougerot-Pocidalo, M. A. and Dang, P. M. C. (2016) Priming of the neutrophil respiratory burst: role in host defense and inflammation. Immunological Reviews. 273, 180-193

17 Groemping, Y. and Rittinger, K. (2005) Activation and assembly of the NADPH oxidase: a structural perspective. Biochemical Journal. 386, 401-416

18 Mehta, P., McAuley, D. F., Brown, M., Sanchez, E., Tattersall, R. S. and Manson, J. J. (2020) COVID-19: consider cytokine storm syndromes and immunosuppression. Lancet. 395, 1033-1034

19 Kruger, P., Saffarzadeh, M., Weber, A. N., Rieber, N., Radsak, M., von Bernuth, H., Benarafa, C., Roos, D., Skokowa, J. and Hartl, D. (2015) Neutrophils: Between host defence, immune modulation, and tissue injury. PLoS Pathog. 11, e1004651

20 Yang, W., Tao, Y., Wu, Y., Zhao, X., Ye, W., Zhao, D., Fu, L., Tian, C., Yang, J., He, F. and Tang, L. (2019) Neutrophils promote the development of reparative macrophages mediated by ROS to orchestrate liver repair. Nat Commun. 10, 1076

21 Kienle, K. and Lammermann, T. (2016) Neutrophil swarming: an essential process of the neutrophil tissue response. Immunol Rev. 273, 76-93

22 Kolaczkowska, E. and Kubes, P. (2013) Neutrophil recruitment and function in health and inflammation. Nat Rev Immunol. 13, 159-175

23 Mortaz, E., Alipoor, S. D., Adcock, I. M., Mumby, S. and Koenderman, L. (2018) Update on Neutrophil Function in Severe Inflammation. Front Immunol. 9, 2171

24 Pechous, R. D. (2017) With Friends Like These: The Complex Role of Neutrophils in the Progression of Severe Pneumonia. Front Cell Infect Microbiol. 7, 160

25 de Oliveira, S., Rosowski, E. E. and Huttenlocher, A. (2016) Neutrophil migration in infection and wound repair: going forward in reverse. Nat Rev Immunol. 16, 378-391 
26 Huang, C., Wang, Y., Li, X., Ren, L., Zhao, J., Hu, Y., Zhang, L., Fan, G., Xu, J., Gu, X., Cheng, Z., Yu, T., Xia, J., Wei, Y., Wu, W., Xie, X., Yin, W., Li, H., Liu, M., Xiao, Y., Gao, H., Guo, L., Xie, J., Wang, G., Jiang, R., Gao, Z., Jin, Q., Wang, J. and Cao, B. (2020) Clinical features of patients infected with 2019 novel coronavirus in Wuhan, China. Lancet. 395, 497-506 27 Swain, S. D., Rohn, T. T. and Quinn, M. T. (2002) Neutrophil priming in host defense: role of oxidants as priming agents. Antioxid Redox Signal. 4, 69-83

28 Ostuni, M. A., Gelinotte, M., Bizouarn, T., Baciou, L. and Houee-Levin, C. (2010) Targeting NADPH-oxidase by reactive oxygen species reveals an initial sensitive step in the assembly process. Free Radical Biology and Medicine. 49, 900-907

29 Ostuni, M. A., Bizouarn, T., Baciou, L. and Houee-Levin, C. (2011) Modulation of the Activity of the Nadph Oxidase System by Reactive Oxygen Species: Influence of Catalase. Radiation Protection Dosimetry. 143, 166-171

30 Nathan, C. and Cunningham-Bussel, A. (2013) Beyond oxidative stress: an immunologist's guide to reactive oxygen species. Nat Rev Immunol. 13, 349-361

31 Liumbruno, G., Bennardello, F., Lattanzio, A., Piccoli, P. and Rossetti, G. (2009) Recommendations for the transfusion of red blood cells. Blood Transfusion. 7, 49-64

32 Rivet, C., Baxter, A. and Rock, G. (1989) Potassium Levels in Irradiated Blood. Transfusion. 29, 185-185

33 Dinning, G., Doughty, R. W., Reid, M. M. and Lloyd, H. L. (1991) Potassium Concentrations in Irradiated Blood. British Medical Journal. 303, 1110-1110

34 Weiss, B., Hoffmann, M., Anders, C., Hellstern, P., Schmitz, N. and Uppenkamp, M. (2004) Gamma-irradiation of blood products following autologous stem cell transplantation: surveillance of the policy of 35 centers. Ann Hematol. 83, 44-49

35 Spiryda, L. B., Laufer, M. R., Soiffer, R. J. and Antin, J. A. (2003) Graft-versus-host disease of the vulva and/or vagina: diagnosis and treatment. Biol Blood Marrow Transplant. 9, 760-765

36 Lee, S. J., Vogelsang, G. and Flowers, M. E. (2003) Chronic graft-versus-host disease. Biol Blood Marrow Transplant. 9, 215-233

37 Pelszynski, M. M., Moroff, G., Luban, N. L. C., Taylor, B. J. and Quinones, R. R. (1994) Effect of Gamma-Irradiation of Red-Blood-Cell Units on T-Cell Inactivation as Assessed by Limiting Dilution Analysis - Implications for Preventing Transfusion-Associated Graft-VersusHost Disease. Blood. 83, 1683-1689

38 Spinks, J. W. T. and Woods, R. J. (1990) Introduction to radiation chemistry. 3rd edition Wiley NY

39 Nauseef, W. M. (2014) Isolation of human neutrophils from venous blood. Methods Mol Biol. 1124, 13-18

40 Bizouarn, T., Souabni, H., Serfaty, X., Bouraoui, A., Masoud, R., Karimi, G., HoueeLevin, C. and Baciou, L. (2019) A Close-Up View of the Impact of Arachidonic Acid on the Phagocyte NADPH Oxidase. Nadph Oxidases: Methods and Protocols. 1982, 75-101

41 Sumimoto, H., Takeshige, K. and Minakami, S. (1984) Superoxide Production of Human Polymorphonuclear Leukocytes Stimulated by Leukotriene-B4. Biochimica Et Biophysica Acta. 803, 271-277

42 Engelich, G., White, M. and Hartshorn, K. L. (2001) Neutrophil survival is markedly reduced by incubation with influenza virus and Streptococcus pneumoniae: role of respiratory burst. J Leukoc Biol. 69, 50-56

43 Towbin, H., Staehelin, T. and Gordon, J. (1979) Electrophoretic Transfer of Proteins from Polyacrylamide Gels to Nitrocellulose Sheets - Procedure and Some Applications. Proceedings of the National Academy of Sciences of the United States of America. 76, 43504354 
44 Baciou, L., Erard, M., Dagher, M. C. and Bizouarn, T. (2009) The cytosolic subunit p67(phox) of the NADPH-oxidase complex does not bind NADPH. Febs Letters. 583, 3225-3229 45 Oh, H., Siano, B. and Diamond, S. (2008) Neutrophil isolation protocol. J Vis Exp

46 Hurtado-Nedelec, M., Makni-Maalej, K., Gougerot-Pocidalo, M. A., Dang, P. M. and ElBenna, J. (2014) Assessment of priming of the human neutrophil respiratory burst. Methods Mol Biol. 1124, 405-412

47 Summers, C., Rankin, S. M., Condliffe, A. M., Singh, N., Peters, A. M. and Chilvers, E. R. (2010) Neutrophil kinetics in health and disease. Trends in Immunology. 31, 318-324

48 Dancey, J. T., Deubelbeiss, K. A., Harker, L. A. and Finch, C. A. (1976) Neutrophil kinetics in man. J Clin Invest. 58, 705-715

49 Tak, T., Tesselaar, K., Pillay, J., Borghans, J. A. M. and Koenderman, L. (2013) What's your age again? Determination of human neutrophil half-lives revisited. Journal of Leukocyte Biology. 94, 595-601

50 Lahoz-Beneytez, J., Elemans, M., Zhang, Y., Ahmed, R., Salam, A., Block, M., Niederalt, C., Asquith, B. and Macallan, D. (2016) Human neutrophil kinetics: modeling of stable isotope labeling data supports short blood neutrophil half-lives. Blood. 127, 3431-3438

51 Simon, H. U. (2001) Regulation of eosinophil and neutrophil apoptosis - similarities and differences. Immunological Reviews. 179, 156-162

52 Suratt, B. T., Young, S. K., Lieber, J., Nick, J. A., Henson, P. M. and Worthen, G. S. (2001) Neutrophil maturation and activation determine anatomic site of clearance from circulation. American Journal of Physiology-Lung Cellular and Molecular Physiology. 281, L913-L921

53 Watson, F., Robinson, J. J. and Edwards, S. W. (1992) Neutrophil Function in WholeBlood and after Purification - Changes in Receptor Expression, Oxidase Activity and Responsiveness to Cytokines. Bioscience Reports. 12, 123-133

54 Winterbourn, C. C., Hampton, M. B., Livesey, J. H. and Kettle, A. J. (2006) Modeling the reactions of superoxide and myeloperoxidase in the neutrophil phagosome: implications for microbial killing. J Biol Chem. 281, 39860-39869

55 Brugnara, C. and Churchill, W. H. (1992) Effect of Irradiation on Red-Cell Cation Content and Transport. Transfusion. 32, 246-252

56 Pick, E. (2020) Cell-Free NADPH Oxidase Activation Assays: A Triumph of Reductionism. Methods Mol Biol. 2087, 325-411

57 Bass, D. A., Seeds, M. C., Jones, D. F., Chilton, F. H. and Bauldry, S. A. (1994) Priming of Phospholipases a(2) of Human Neutrophils by Tumor-Necrosis-Factor. Chest. 105, S99-S100

58 Atkinson, Y. H., Murray, A. W., Krilis, S., Vadas, M. A. and Lopez, A. F. (1990) Human Tumor Necrosis Factor-Alpha (Tnf-Alpha) Directly Stimulates Arachidonic-Acid Release in Human Neutrophils. Immunology. 70, 82-87

59 Seeds, M. C., Jones, D. F., Chilton, F. H. and Bass, D. A. (1998) Secretory and cytosolic phospholipases $\mathrm{A}(2)$ are activated during TNF priming of human neutrophils. Biochimica Et Biophysica Acta-Lipids and Lipid Metabolism. 1389, 273-284

60 Segal, A. W. and Abo, A. (1993) The Biochemical Basis of the Nadph Oxidase of Phagocytes. Trends in Biochemical Sciences. 18, 43-47

61 Karimi, G., Levin, C. H., Dagher, M. C., Baciou, L. and Bizouarn, T. (2014) Assembly of phagocyte NADPH oxidase: A concerted binding process? Biochimica Et Biophysica ActaGeneral Subjects. 1840, 3277-3283

62 Dewas, C., Dang, P. M. C., Gougerot-Pocidalo, M. A. and El-Benna, J. (2003) TNFalpha induces phosphorylation of p47(phox) in human neutrophils: Partial phosphorylation of $\mathrm{p} 47$ (phox) is a common event of priming of human neutrophils by TNF-alpha and granulocytemacrophage colony-stimulating factor. Journal of Immunology. 171, 4392-4398 
63 Boussetta, T., Gougerot-Pocidalo, M. A., Hayem, G., Ciappelloni, S., Raad, H., Derkawi, R. A., Bournier, O., Kroviarski, Y., Zhou, X. Z., Malter, J. S., Lu, P. K., Bartegi, A., Dang, P. M. C. and El-Benna, J. (2010) The prolyl isomerase Pin1 acts as a novel molecular switch for TNFalpha-induced priming of the NADPH oxidase in human neutrophils. Blood. 116, 5795-5802

64 Potera, R. M., Jensen, M. J., Hilkin, B. M., South, G. K., Hook, J. S., Gross, E. A. and Moreland, J. G. (2016) Neutrophil azurophilic granule exocytosis is primed by TNF-alpha and partially regulated by NADPH oxidase. Innate Immun. 22, 635-646 


\section{Supplementary materials for this manuscript include the following:}

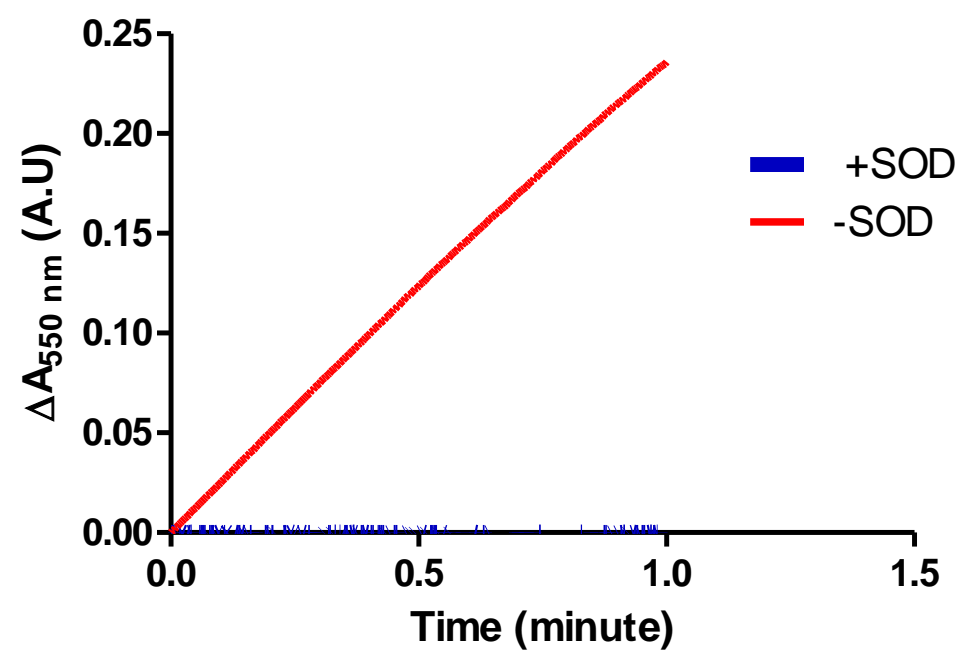

Figure S1: Kinetics of superoxide anion production. Membrane fractions $(4 \mathrm{nM})$ and cytosolic proteins (p47 ${ }^{\text {phox }},{\mathrm{p} 67^{\text {phox }}}$ and Rac1Q61L; on average $300 \mathrm{nM}$ each) were put in PBS solution supplemented with 10 $\mathrm{mM} \mathrm{MgSO} 4$ in a spectrophotometer cuvette and incubated in the presence of AA $(44 \mu \mathrm{M})$ for 5 min at 25 ${ }^{\circ} \mathrm{C}$. The total volume of the solution was $600 \mu \mathrm{L} .50 \mu \mathrm{M}$ of cyt c and $200 \mu \mathrm{M}$ of NADPH were then added and the reaction was followed at $550 \mathrm{~nm}$ during $1 \mathrm{~min}$ (in red). Parallel control experiment (in blue) was performed in the presence of $50 \mu \mathrm{g} / \mathrm{mL}$ SOD. 


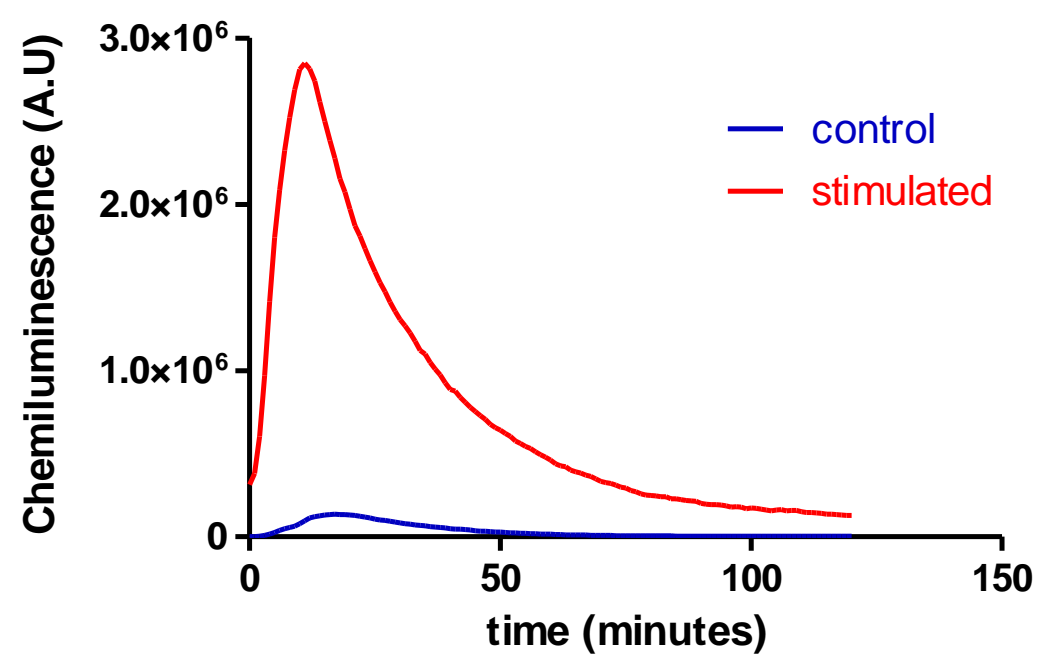

Figure S2: Intracellular and extracellular ROS production of neutrophils: chemiluminescence plot generated by neutrophils before (blue) and after (red) stimulation. Neutrophils were allowed to phagocytosed zymosan opsonised with human serum and the ROS production was determined by chemiluminescence generated by the reaction of HRP and LO12 (red). The ratio of neutrophils to opsonised zymosan was 1:5. In blue: chemiluminescence plot generated by unstimulated neutrophils. 


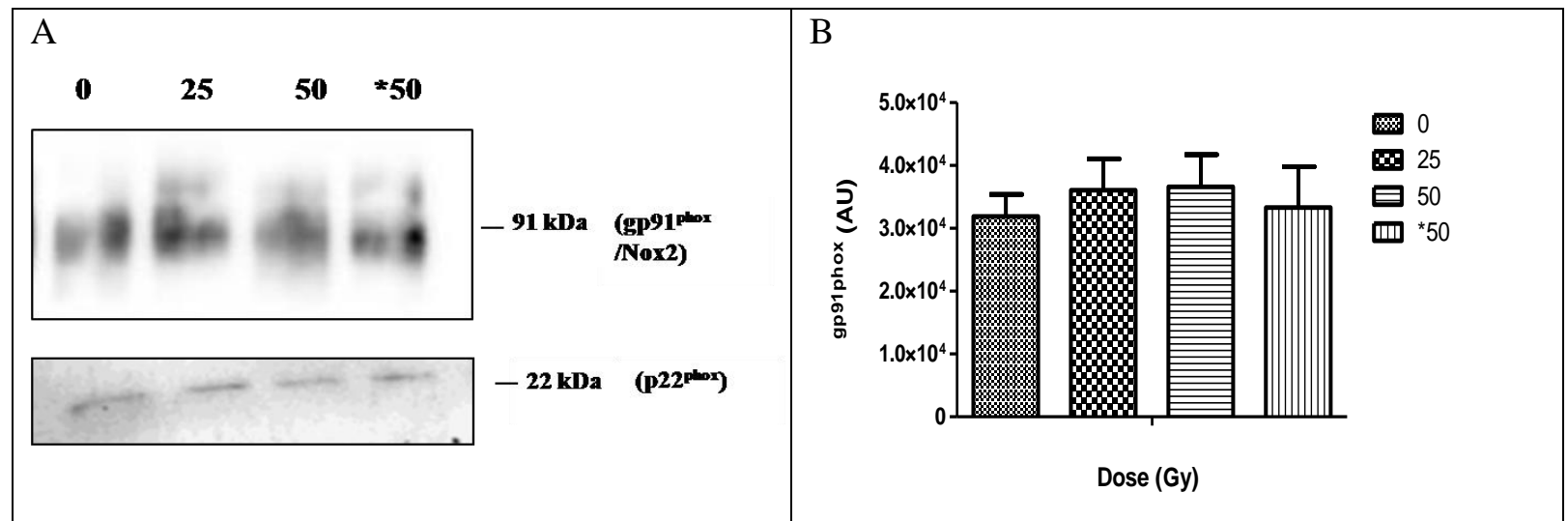

Figure S3. Characterization of cytb $_{558}$ in membrane fractions from irradiated and nonirradiated neutrophils A Western blot of membrane fractions (gp91 ${ }^{\text {phox }}$ and p22). Lane 1: Sham (non-irradiated neutrophils), lane 2, 3 and 4 represent neutrophils irradiated at 25 Gy, 50 Gy and $* 50$ Gy respectively. In each lane, $n=1 * 10^{-6} \mu$ mol of cytb s58 (estimated from the absorption change spectra). The membrane fractions were heated for 5 minutes at $85{ }^{\circ} \mathrm{C}$, and subject to $10 \%$ SDS-PAGE and immunoblotting. Each membrane was incubated with a primary antibody (dilution 1:1500 for gp91 ${ }^{\text {phox }}$ and $\left.\mathrm{p} 22^{\text {phox }}\right)$. B. Band intensity of gp91 ${ }^{\text {phox }}$ quantified by densitometry using ImageJ software. Results are expressed as mean \pm SEM $(n=3)$. 


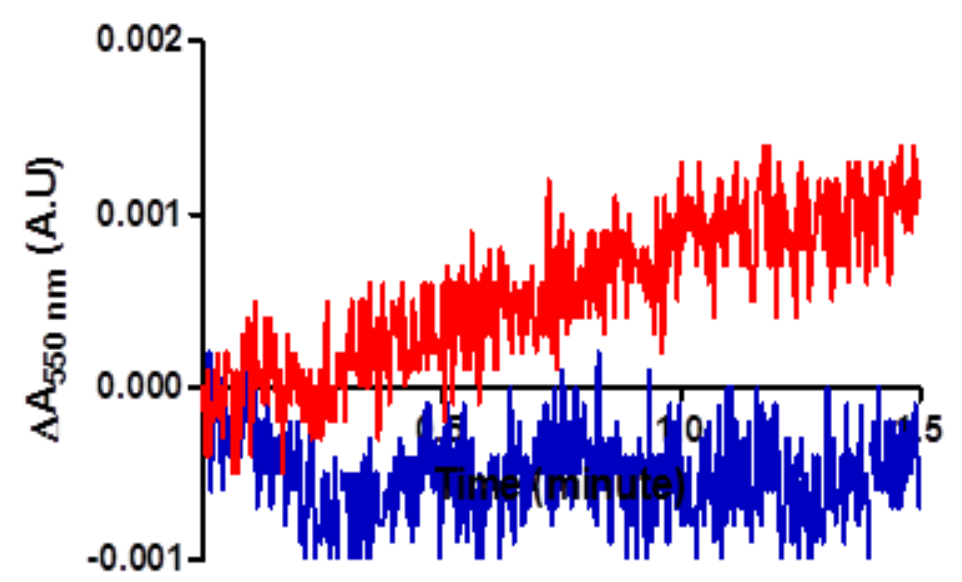

Figure S4: Kinetics of superoxide anion production. Membrane fractions (4 $\mathrm{nM}$ cyt $\left.b_{558}\right)$ from $50 \mathrm{~Gy}$ irradiated neutrophils and cytosolic proteins (p47 ${ }^{\text {phox }}, \mathrm{p} 67^{\text {phox }}$ and Rac1Q61L; on average $300 \mathrm{nM}$ each) were incubated in activity buffer (PBS solution supplemented with $10 \mathrm{mM} \mathrm{MgSO}{ }_{4}$ ) for 5 minutes in a spectrophotometer cuvette at $25{ }^{\circ} \mathrm{C}$. $50 \mu \mathrm{M}$ of cyt $c$ and $200 \mu \mathrm{M}$ of NADPH were then added and the reaction was followed at $550 \mathrm{~nm}$ during $2 \mathrm{~min}$ (in red). Parallel control experiment (in blue) was performed in the presence of $5 \mu \mathrm{M}$ DPI. 


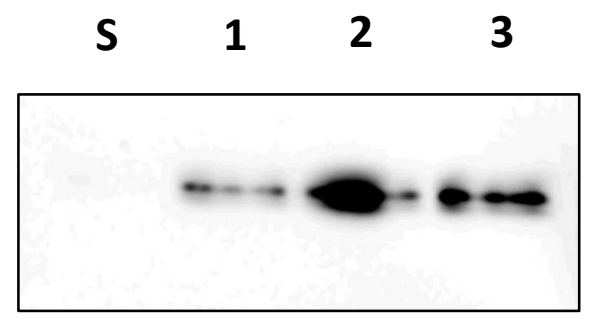

\section{7 kDa}

Figure S5: Western blot analysis of membrane fractions isolated from irradiated and $\mathrm{H}_{2} \mathrm{O}_{2}$ incubated cells. S: Sham (neutrophil plasma membrane), 1: purified plasma membrane of neutrophils incubated with $18 \mu \mathrm{M} \mathrm{H}_{2} \mathrm{O}_{2}$ (as $25 \mathrm{~Gy}$ ), 2: purified plasma membrane of neutrophils incubated with $36 \mu \mathrm{M} \mathrm{H}_{2} \mathrm{O}_{2}$ (as 50 Gy) and 3: purified plasma membrane of neutrophils $50 \mathrm{~Gy}$. In each lane, $20 \mu \mathrm{g}$ of proteins were used and incubated with antibodies against the proteins. 